\title{
CORPORATE REGISTRATION: A FUNCTIONAL ANALYSIS OF "DOING BUSINESS"*
}

A RECENT case before the United States Supreme Court ${ }^{1}$ occasioned that body's latest effort to define the domain protected by that sacred but highly abstruse constitutional principle-freedom of interstate commerce. ${ }^{2}$ In question was a state statutory scheme providing for the registration of foreign corporations ${ }^{3}$ and for the closing of state courts to actions in contract brought by non-complying companies. ${ }^{4}$ Dismissal of a Fair Trade action ${ }^{5}$ brought by a foreign corporation was affirmed by the Court upon a determination that certain of the company's activities in the state were sufficiently "intrastate" so as to justify the exercise of state power and remove the corporation from the protection of the "commerce clause" as to the registration requirement." This conclusion was reached through a somewhat mechanical matching of cases which seems to have led to the selection of the label "intrastate" for activities which would not seem to be of such purely local concern as to merit that unqualified classification. This narrow approach had the effect of precluding an investigation into whether the state's interest in this particular type of statute and in the activities in question is actually great enough to justify the imposition on the foreign corporation of the specific burdens involved. It is suggested that a consideration of these broader issues and a proper recognition of the relation of the questioned activities to interstate commerce would have resulted in the application of commerce clause protection in this case.

The case originated as a suit under the New Jersey Fair Trade Law, ${ }^{7}$ brought by Eli Lilly and Company, a nationally known drug manufacturer

\#Eli Lilly \& Co. v. Sav-On-Drugs, Inc., 366 U.S. 276 (1961).

1. Eli Lilly \& Co. v. Sav-On-Drugs, Inc., 366 U.S. 276 (1961).

2. This principle is of course derived from the "commerce clause" of the federal Constitution: "[The Congress shall have Power] to regulate Commerce with foreign Nations, and among the several States, and with the Indian Tribes ...." U.S. CoNST. art. I, \& 8, cl. 3. This clause, it is true, says nothing about forbidding to the states either concurrent power over commerce or power in the absence of relevant congressional action in a given field. Nevertheless, it early became the foundation for the doctrine of a general freedom of interstate commerce from "undue burdens" imposed by the states and from state regulation in fields which in the Court's view admit of only national regulation, regardless of whether Congress has actually acted on them. See generally Poweli, VAGaries and VARIETIEs in Constitutional. Interpretation 142-79 (1956); Anderson, State Regullation of Interstate Commerce, 61 DICK. L. REv. 1 (1956).

3. N.J. Rev. Stat. \$ 14:15-3 (1937).

4. N.J. Rev. Stat. \& 14:15-4 (1937).

5. Entered by trial court, Eli Lilly \& Co. v. Sav-On-Drugs, Inc., 57 N.J. Super. 291, 154 A.2d 650 (1959), aff'd, 31 N.J. 591, 158 A.2d 528 (1960).

6. 366 U.S. at $282-84$.

7. N.J. REv. Stat. $\$ \S 56: 4-3$ through $56: 4-6$ (1937). These provisions enable a manufacturer to establish a minimum retail price structure for his branded products by securing contractual agreement to such prices on the part of retailers who will sign; the force of the Law lies in its enforcement of this price structure against non-signing retailers as well. 
incorporated in Indiana, against Sav-on-Drugs, Inc., a New Jersey retailer, for an injunction against the cut-rating of Lilly drug products. ${ }^{8}$ The defendant claimed that Lilly was barred from bringing the suit under a penalty provision of the New Jersey registration statutes. ${ }^{9}$ The statutes require that every foreign corporation, before "transacting any business in this state," obtain a certificate to do business from the secretary of state by filing copies of its charter and certificate of incorporation, together with statements of its capital stock structure, of the character of the business, and of the principal office and agent for service of process in the state..$^{10}$ One of the sanctions imposed for violation is that, until this certificate is obtained, the corporation "shall not maintain any action in this state upon any contract made by it in this state."11 Lilly's New Jersey business consisted primarily of interstate shipments to wholesalers in the state. ${ }^{12}$ However, the company also maintained an office in Newark with eighteen "detailmen" whose job it was to promote the use of Lilly drug products through visits to hospitals, retail druggists, and physicians. Their efforts were strictly promotional, however, for orders could be accepted and filled only by the wholesalers, although on occasion a detailman would transmit an order to a wholesaler as a service to a retailer. ${ }^{13}$ The trial court concluded from these facts that the company was "transacting business" in the state ${ }^{14}$ and also concluded that the action was on an implied contract under the Fair Trade Law. ${ }^{15}$

8. 57 N.J. Super. at 293-94, 154 A.2d at 651 . The suit was against Sav-On as a nonsigner for violation of the Fair Trade price structures established by Lilly through some 1500 contracts with signing New Jersey retailers. Ibid. See note 7 supra.

9. N.J. Rev. Stat. \$ 14:15-3 through 14:15-7 (1937). The defendant seems to have had no other substantial defense. 57 N.J. Super. at 295, 154 A.2d at 652. Raising this statute was an ingenious defense on the part of counsel for Sav-On, for prior to this suit Lilly had successfully prosecuted more than thirty similar Fair Trade suits in New Jersey state courts. Brief for Appellant, pp. 3-4, Eli Lilly \& Co. v. Sav-On-Drugs, Inc., 366 U.S. 276 (1961).

10. N.J. Rev. Stat. $\$ 14: 15-3$ (1937). This section does not apply to banking, insurance, ferry, or railroad corporations. Another section requires the payment of a ten dollar fee for the filing of these papers. N.J. Rev. Stat. \$ 14:16-1 (1937). This fee is clearly incidental to the registration requirement and merely to cover clerical costs of the filing; it is not to be judged as a tax. See Sprout v. City of South Bend, 277 U.S. 163, 169 (1928).

11. N.J. Rev. Stat. \& 14:15-4 (1937). The corporation might also be barred from other types of suits under a "spite" provision requiring that burdens imposed on New Jersey corporations transacting business in other states should be similarly imposed on corporations of those states transacting business in New Jersey, regardless of the independent requirements of New Jersey law. N.J. Rev. Stat. $\$ 14: 15-5$ (1937). In addition, there is a provision for a fine of two hundred dollars "for each offense." N.J. Rev. Srar. $\$ 14: 15-6$ (1937). There is no indication that prior to this decision the State of New Jersey made any attempt to enforce this statute against Lilly by means of the fine or by injunction, possibly because it had never occurred to anyone that the company was constitutionally registerable until Sav-On raised the issue.

12. See 57 N.J. Super. at $298-99,154$ A.2d at 654 .

13. 57 N.J. Super. at $298-99,154$ A.2d at 654 .

14. See 57 N.J. Super, at 300,154 A.2d at 655 .

15. 57 N.J. Super. at $305-06,154$ A.2d at 658 . The court considered this an action upon an "implied contract" in the sense that the price structure to be enforced was that set up 
The terms of the statute thereby being met, the motion for dismissal was granted. ${ }^{10}$ The Supreme Court of New Jersey affirmed, ${ }^{17}$ and appeal was taken to the United States Supreme Court.

The Court accepted as firmly established the doctrine that such a statute could not constitutionally be applied to a corporation engaged exclusively in "interstate" commerce. ${ }^{18}$ It thus centered its attention on the issue of whether there were Lilly activities in New Jersey which could be labelled "intrastate" in order to validate the application of a registration requirement. This question was apparently treated as one involving merely a choice between two alternative precedents. Lilly urged ${ }^{19}$ as applicable the "drummer" cases, ${ }^{20}$ which held that a state cannot impose a license tax upon agents of a foreign corporation seeking merely to "drum up" interstate sales through solicitation of direct buyers for goods to be shipped into the state, such solicitation being regarded as an integral part of interstate commerce. But the Court felt that Lilly, rather than merely soliciting interstate sales, was engaged in "inducing" local sales between New Jersey retailers and wholesalers, the latter alone being Lilly's direct customers. ${ }^{21}$ For this reason the Court deemed controlling Cheney Bros. Co. v. Massachusetts, 22 in which it had found sufficient local business to validate a state excise tax where a company maintained a staff of men who promoted the merits of the company's flour through visits to retailers and who regularly transmitted orders from such retailers to the wholesalers. ${ }^{23}$ Four Justices dissented, ${ }^{24}$ insisting that Cheney did not apply because the Lilly detailmen did not regularly transmit orders. ${ }^{25}$

by contractual agreement with New Jersey retailers but that the right to enforce that price structure against non-signers was that given by virtue of the Fair Trade Law alone. Ibid. See also discussion of the Fair Trade Law at notes 7 and 8 supra.

16. This dismissal apparently was without prejudice, for the bar to suits is lifted immediately upon registration, however delayed. See note 60 infra.

17. 31 N.J. 591, 158 A.2d 528 (1960).

18. 366 U.S. at 278. See, e.g., Buck Stove \& Range Co. v. Vickers, 226 U.S. 205 (1912) ; International Textbook Co. v. Pigg, 217 U.S. 91 (1910) ; Crutcher v. Kentucky, 141 U.S. 47 (1S91) (which involved a corporation doing some intrastate business but which nevertheless sets forth the principle).

19. Brief for Appellant, p. 30; Reply Brief for Appellant, p. 4.

20. E.g., Memphis Steam Laundry Cleaner, Inc. v. Stone, 342 U.S. 389 (1952) (partial list of drummer cases set out in this case at pp. 392-93 n.7); Real Silk Hosiery Mills v. City of Portland, 268 U.S. 325 (1925) ; Brennan v. Titusville, 153 U.S. 289 (1894) ; Robbins v. Shelby County Taxing Dist., 120 U.S. 489 (1887).

21. 366 U.S. at $281-82$.

22. 246 U.S. 147 (1918).

23. Id. at 155. This case consisted of tax collection actions against seven corporations operating into Massachusetts. The flour company involved in the section of the case relied upon by the Court was the Northwestern Consolidated Milling Company, of Minnesota, and reference in the text to Cheney hereafter, unless otherwise specified, will indicate the decision as to the flour company.

24. Mr. Justice Douglas wrote the dissent, in which Justices Frankfurter, Whittaker, and Stewart concurred. Mr. Justice Black wrote the opinion of the Court, and Mr. Justice Harlan wrote a concurring opinion.

25. 366 U.S. at 290-92. In this dissent and in Note, 75 HARv. L. REv. 138, 139 (1961), 
It is evident from the opinions in Lilly that the Justices essentially limited their consideration of the case to a determination as to which of the available alternative precedents involved a sales situation more closely analogous to Lilly's promotional scheme. The label "intrastate" was finally chosen entirely by reference to the Cheney facts with no apparent investigation into the reasonableness of so labelling the detailmen's activities or of thus upholding the registration of the foreign corporation. ${ }^{26}$ This approach would seem to assume that the question of whether or not an activity is "intrastate" can be determined without reference to the specific purpose for which the label is to be attached. Yet the long history of judicial struggles with the commerce clause indicates that the elaborate language of "interstate" and "intrastate" is primarily a tool to explain conclusions adopted by the Court. ${ }^{27}$ The underlying

the assertion is made that the activities of the Lilly detailmen were precisely those determined to be "exclusively in furtherance of interstate commerce" in Northwestern States Portland Cement Co. v. Minnesota, 358 U.S. 450, 455 (1959). That case upheld the right of a state to impose a net income tax upon profits derived from interstate commerce if apportioned to activities in the taxing state. However, while that case did indeed involve promotion men making visits to the contractors and other users of cement sold only to wholesalers in interstate commerce for resale to ultimate purchasers, nevertheless, it is clear that the whole decision was predicated upon an assumption of purely interstate business without regard to the nature of the activities, which, admittedly, are listed in the opinion. Mr. Justice Whittaker in his dissenting opinion in that case suggested the probable motivation for the concentration on the issue of the net income tax as imposed upon a purely interstate business: it was clearly to the state's advantage to secure a decision validating the tax as applied not just to intrastate business but also to any corporation operating into its territory. $I d$, at 477-79 n.1. The conclusion that must be drawn is that the Court in that case simply did not pass on the nature of the promotional activities before it. Mr. Justice Harlan, concurring with the majority in Lilly, characterized the allegedly crucial words in Northwestern as "a casual reference which was quite unnecessary to the issue decided by the Court in that case." Concurring opinion, 366 U.S. at 287 n.3.

26. This is certainly evidenced by the opinions of the Court and of the dissent. The concurring opinion of Mr. Justice Harlan indicates considerably more awareness of the problem of competing state and federal interests. Indeed, toward the end of his opinion he states that he is not prepared to extend the protection of the drummer cases to the Lilly detailmen when "the countervailing federal considerations are as thin as they seem to me to be here ...." 366 U.S. at 288 . But his balancing appears to be confined strictly to differentiating the Lilly detailmen from the drummers on the ground that the activities of the latter in soliciting interstate sales are essential to interstate commerce and that Lilly's direct visits to the physicians are not. The latter part of this judgment appears unsound in view of the vital role of the detailman in the interstate sale of Lilly drug products. See notes 73-77 infra and accompanying text. Moreover, Mr. Justice Harlan makes no investigation of the actual state interest in securing this registration.

27. An analogous use of language is illustrated by the history of a landmark case in commerce clause development, Cooley v. Board of Wardens, 53 U.S. (12 How.) 299 (1851), upholding the validity of local pilotage regulations on the ground that the commerce clause did not require uniformity in that area. The so-called "Cooley rule" was set forth by that case, that some subjects of regulation are national in nature and require uniformity of regulation, while others admit of diversity of regulation and are hence local in nature. One commentator, writing of the balancing of federal and state interests in commerce clause cases, has written: "This does not mean, however, that the Cooley formula is a useless 
philosophy of the commerce clause doctrine appears to be to permit states to exercise maximum local control consonant with the preservation of a relatively integrated national economy. Theoretically, the application of such a philosophy would require an investigation of these competing interests in every case, since virtually every business activity today has some "interstate" ramifications. In practice, however, an activity may be so localized that the Court, for reasons of judicial convenience, will employ the label "intrastate" to indicate that no further case-by-case investigation of federal interests is warranted. ${ }^{28}$ But there appears to be a broad borderline area in which the label "intrastate" is used merely to explain the result in a given case upholding the validity of a particular exercise of state power. ${ }^{29}$ Within this borderline area, reliance upon the matching of fact situations in the application of labels may result in neglect of the underlying competition of interests.

This problem is evident in the Lilly case, for neither the rejected line of drummer cases nor the Cheney ${ }^{30}$ precedent deemed controlling represent conclusions as to the validity of a police power registration statute. The statute examined in Cheney was a provision exacting an excise tax from foreign corporations transacting business in the state ${ }^{31}$ and hence based upon the state's revenue power. Similarly, the drummer cases ${ }^{32}$ were, in effect, tax cases:

thing thrown into the situation to delude lawyers into believing that the areas of state power are well defined .... The nature of the subject matter-local or not local-becomes the point of comparison.... After the issue has been resolved, the Cooley formula is helpful in explaining the result in relation to precedents. $* *$ Discrimination likewise is a term used to describe conclusions of relative values. The all important problem again is the weighing of local values gained by virtue of a local regulation against national values harmed by virtue of that regulation. If the national values are of greater importance, the invalidity of the regulation can be explained in terms of discrimination." Anderson, State Regulation of Interstate Commerce, 61 Dick. L. Rev. 1, 27 (1956).

28. A business activity which the Court apparently has determined to be so localized as to warrant an unqualified label of "intrastate" is that of the "peddler" who carries his goods with him on his rounds seeking sales. See note 44 infra and Wagner v. City of Covington, 251 U.S. 95 (1919) (soft drink "peddler" bringing goods across state line by wagon and carting them from store to store seeking sales). If such an unconditional label is applied, a matching of fact situations in later cases becomes justified, for the requirements of due process are presumably the only limits on the power of the state.

29. This appears to be the case in Cheney Bros. Co. v. Massachusetts, 246 U.S. 147 (1918), which the Lilly Court deemed controlling. See notes 22 and 23 supra and accompanying text. If the Court in that case intended to put an unconditional label of "intrastate" upon the activities of the flour promotion men there, the decision must be considered unsound, for this is clearly a borderline area, as is indicated by the confusion produced by certain language in Northwestern States Portland Cement Co. v. Minnesota, 358 U.S. 450, 452, 455 (1959). See note 25 supra. Hence it seems doubtful that the Court in Cheney intended anything more than an explanation of its decision as to the tax in question.

30. Cheney Bros. Co. v. Massachusetts, supra note 29.

31. The annual excise tax imposed upon foreign corporations for the transaction of local business was calculated at $1 / 50$ of $1 \%$ of the par value of the capital stock of the corporation, with a maximum amount of $\$ 2000$ in tax. 246 U.S. at 147.

32. See cases cited at note 20 supra. The namesake case of Cheney Bros. Co. v. Massachusetts actually echoes the drummer cases, for the Cheney excise tax was struck down as 
while generally cited for the principle of freedom of interstate commerce from state licensing, ${ }^{33}$ they each nevertheless involved license fees which were clearly greater than amounts required for the administration of the licensing system and which hence should be considered as taxes upon the privilege of doing the business in question. ${ }^{34}$

Tax cases involve different considerations from cases arising under the police power. In the former, the factors to be reconciled are the federal interest in the freedom of interstate commerce from state imposed financial burdens and the state's fundamental interest in exacting taxes ${ }^{35}$ from those who enjoy the benefits of the public order secured by the state. The primary test underlying these cases, although not usually made explicit, would seem to be whether the corporation can be said to have benefited sufficiently from the power of the state so that, in fairness, it should bear the cost of state government to the degree required by the tax in question. ${ }^{36}$ Several factors are involved in this

to that company only, a Connecticut silk manufacturer selling by sample in Massachusetts with orders being accepted and filled only in the home state. 246 U.S. at 153.

33. See, e.g., the majority opinion in the Lilly case, 366 U.S. at 278-79; the concurring opinion, 366 U.S. at 284-85; the dissent, 366 U.S. at 289-92; Northwestern States Portland Cement Co. v. Minnesota, 358 U.S. 450, 458 (1959) ; Wagner v. City of Covington, 251 U.S. 95, 103 (1919).

34. See, e.g., Nippert v. Richmond, 327 U.S. 416 (1946) ( $\$ 50$ each year plus $I / 2$ of $1 \%$ of receipts greater than $\$ 1000$ in the preceding year); Best \& Co. v. Maxwell, 311 U.S. 454 (1940) ( $\$ 250$ license tax on every person not a regular retail merchant who displayed samples in hotel rooms) ; Crenshaw v. Arkansas, 227 U.S. 389 (1913) (annual fee of $\$ 200$ for each county) ; Robbins v. Shelby County Taxing Dist., 120 U.S. 489 (1887) (tax on drummer of $\$ 10$ a week or $\$ 25$ a month to operate in the county). In Brennan v. Titusville, 153 U.S. 289, 299 (1894), the Court stated explicitly that the license under consideration did not purport to come under the police power but rather was under the taxing power and to be judged as such.

While Mr. Justice Douglas in his dissent did distinguish between the Lilly case and the net income tax cases (see note 36 infra) and criticized the majority for confusing the two, he found no fault with majority's assumption of the relevance of the drummer license tax cases to registration problems in general and indeed thought that the drummer cases should control the Lilly question. 366 U.S. at 290-92.

35. "A 'tax' is an enforced burden of contribution imposed by sovereign right for the support of the government, the administration of the law, and to execute the various functions the sovereign is called upon to perform." City of Orlando v. State, 67 So. $2 \mathrm{~d} 673,674$ (Fla. 1953), quoting Klemm v. Davenport, 100 Fla. 627, 631, 129 So. 904, 908 (1930).

36. For example, the case of Northwestern States Portland Cement Co. v. Minnesota, 358 U.S. 450 (1959) upheld a state tax on net income apportioned to the amount of interstate business transacted in the taxing state by the foreign corporation. In its opinion the Court stated: "While it is true that a State may not erect a wall around its borders preventing commerce an entry, it is axiomatic that the founders did not intend to immunize such commerce from carrying its fair share of the costs of the state government in return for the benefits it derives from within the State." Id. at 461-62. United States Glue Co. v. Town of Oak Creek, 247 U.S. 321 (1918) involved a similar tax: "Such a tax, when imposed upon net incomes from whatsoever source arising, is but a method of distributing the cost of government ...." Id. at 329. See also Underwood Typewriter Co. v. Chamberlain, 254 U.S. 113, 121 (1920). In Wisconsin v. J. C. Penney Co., 311 U.S. 435 (1940), the Court said: "A state is free to pursue its own fiscal policies, unembarrassed by the Con- 
test, such as how "localized" the corporation's activities are, ${ }^{37}$ how closely related the tax is to tangible benefits received by the corporation, ${ }^{38}$ and, on a more conceptual level, how readily the tag "intrastate" may be applied."

stitution, if by practical operation of a tax the state has exerted its power in relation to opportunities which it has given, to protection which it has afforded, to benefits which it has conferred by the fact of being an orderly, civilized society." Id. at 444.

This elementary principle of making even interstate commerce "pay its own way" is cvident in Interstate Busses Corp. v. Blodgett, 276 U.S. 245 (1928), holding that a "state may impose a reasonable charge for the use of its highways by motor vehicles" in the form of a mileage tax imposed upon interstate trucking. Id. at 249-50. Compare the case of Sprout v. City of South Bend, 277 U.S. 163 (1928), involving the validity of a license and license fee imposed on an interstate bus company for operating within city limits. One of the grounds for invalidating the license fee was that there was no evidence that the proceeds of the tax were used "as their fair contribution to the cost of constructing and maintaining the public highways." Id. at 170.

See Menard, State Taxation of Interstate Commerce: From Form to Substance and Back Again, 18 Oніо Sт. L.J. 9, 14-20 (1957).

37. The Court seems to look for both substantial physical localization of operations and the presence of transactions consummated within the borders of one state. Thus Cheney Bros. Co. v. Massachusetts, 246 U.S. 147 (1918) (see notes 22-23 supra and accompanying text) upheld taxation not only of the flour company with promotion men in the state but also of a manufacturer of printing equipment selling parts through a local parts depot, of an automobile manufacturer with a local repair service and used car lot, and of two companies holding corporate meetings and keeping corporate records in and mailing dividend payments from the state. In Norton Co. v. Dept. of Revenue, 340 U.S. 534 (1951), a Massachusetts manufacturer of abrasive materials and machines was held subject to an occupation tax calculated on gross receipts including not only direct retail sales to customers from its Chicago sales office but also orders taken by that office for forwarding to and shipment from Massachusetts; the Court indicated that such interstate commerce was taxable where the corporation had so completely mingled its taxable and otherwise nontaxable business.

38. See note 36 supra. The feeling that commerce should be made to pay its own way to the extent of benefits received may be viewed as explaining the Court's dual position "... that a state may tax net income from interstate commerce even though it cannot tax the privilege of engaging in interstate commerce." West Publishing Co. v. McColgan, 27 Cal. 2d 705, 710, 166 P.2d 861, 864 (1946), aff'd per curian, 328 U.S. 823 (1946). (Emphasis added.) The tax on the privilege of doing the business is exacted regardless of the success of the business in the state; the tax on net income is on tangible profits made possible for the particular corporation by the existence of the state as a market. This result is verbalized by the statement that the net income tax, unlike the franchise or excise tax, falls only "indirectly" on the commerce which produced those profits. See Northwestern States Portland Cement Co. v. Minnesota, 358 U.S. 450, 458-62 (1959). The Court has said that the saving feature of the net income tax is that it arises only where profits have been made in the state and hence does not have the deterrent effect on interstate commerce inherent in such a tax as one on gross receipts regardless of profits. United States Glue Co. v. Town of Oak Creek, 247 U.S. 321, 328-29 (1918). All of this concerns only the constitutional position of such taxation, for Congress has responded to Northwestern States with a statute immunizing interstate commerce from taxation based on mere interstate solicitation of sales. Section 101, 73 Stat. 555 (1959), 15 U.S.C. \& 381 (Supp. II 1961). See concurring opinion of Mr. Justice Harlan in Lilly, 366 U.S. at 286-87 n.3.

Whatever the result reached with this test, the Court's explanation may be couched in vague terms of "interstate" and "intrastate" commerce and "direct" and "indirect" burdens. 
Different considerations arise in police power cases involving regulation of a foreign corporation or its products in the interests of the health, welfare, comfort, and safety of the state's citizens. In such a case the Court has, often explicitly, sought to balance the state's interest in the regulation, as measured by its purpose and effectiveness, against the federal interest in freedom of the commerce involved from the burden in question. ${ }^{40}$ This involves consideration of the reasonableness and necessity of the measure, the extent to which the statute deals with matters of peculiarly local concern which can be adequately regulated only by the particular state, and the practical effect of the burden. ${ }^{41}$ The Court's reliance upon the technique of matching the fact situations of the excise and license tax cases against the Lilly registration problem hence seems misplaced.

E.g.: "It is settled that a State may not directly burden interstate commerce, either by taxation or otherwise. But a tax that only indirectly affects the profits or returns from such commerce is not within the rule." United States Glue Co. v. Town of Oak Creek, supra; "A State may, by appropriate legislation, require payment of an occupation tax from one engaged in both intrastate and interstate commerce .... But in order that the fee or tax shall be valid, it must appear that it is imposed solely on account of the intrastate business . . ." Sprout v. City of South Bend, 277 U.S. 163, 170-71 (1928); "The license fee and other things imposed by the Act on plaintiff in error, who initiates for his principals a transaction in foreign commerce, constitute a direct burden on that commerce." DiSanto v. Pennsylvania, 273 U.S. 34, 37 (1927). (See note 66 infra.)

39. The labelling process can involve fine lines. In Browning v. City of Waycross, 233 U.S. 16 (1914), it was decided for the purpose of an occupation tax that the installation of lightning rods admittedly sold in interstate commerce was separable from such commerce and essentially a local business, in spite of the fact that the installation was being done by the very agent who had solicited the order to be sent out of the state to the manufacturer and in spite of the fact that there was no additional charge for the service.

40. This balancing process came quite out into the open under the encouragement of Mr. Justice Stone. In South Carolina State Highway Dept. v. Barnwell Bros., Inc., 303 U.S. 177 (1938), the Court considered and upheld the validity of a state limitation on the width and weight of motor trucks on state highways. "The Court conceded that the state regulation was a burden on interstate commerce but concluded that it was a justifiable burden in view of the particular circumstances and the fact that there was no discrimination against interstate commerce." Anderson, State Regulation of Interstatc Comnicrce, 61 Drck. L. Rev. 1, 13 (1956). A second Stone opinion is that in Southern Pac. Co. v. Arizona, 325 U.S. 761 (1945), invalidating a state law restricting the length of passenger trains to fourteen cars and freight to seventy to avoid the dangers of "slack" between cars of long trains. "The Court believed that uniform regulation of this matter was necessary in order to have an efficient transportation system. In other words the Court made a value judgment. It weighed the local interest in having the regulation against the national interest in not having the regulation and concluded that the national interest was superior." Anderson, supra at 20. Compare Terminal R.R. Ass'n v. Brotherhood of R.R. Trainmen, 318 U.S. 1 (1943), upholding a state law requiring the use of cabooses on freight trains (opinion by Mr. Justice Jackson).

41. Powell writes that the trend is to "sanction state action when from the standpoint of practical considerations it interferes with the national economy no more than is deemed to be justified by the importance of the resulting protection of community interests. Both sides of the scale must be given consideration." Powel, VAGARIES AND VARIETIES IN CONSTItUTIONAL INTERPRETATION 176 (1956). 
As a result the Lilly Court has established a precedent which is highly questionable in terms of the actual interests involved. The law after Lilly may be viewed, for purposes of analysis, as encompassing a spectrum of five principal types of sales situations. At one extreme is the foreign corporation which sends no agents into the state, advertising by mail if at all; it is well established that such a business is protected from demands of registration. ${ }^{42}$ The second situation is that suggested by the drummer cases, ${ }^{43}$ where the company continues to confine itself to interstate sales but sends in agents to "drum up" its business ; ${ }^{44}$ under the reasoning in Lilly the drummer decisions would control even in a registration case, and such a business would not be subject to the statute. ${ }^{45}$ The third in this series is the Lilly situation itself, with the foreign corporation sending "detailmen" to make direct visits to the retailers and physicians who either buy from wholesalers in the state or merely prescribe the drugs to be ordered by the ultimate consumer, the patient; under the present decision this activity is sufficiently "intrastate" for the state to require registration. ${ }^{46}$ The fourth situation, suggested by the facts of the Cheney ${ }^{47}$ case, involves the

42. This is the most elementary example of purely "interstate" commerce and clearly comes under the protection of such a case as International Textbook Co. v. Pigg, 217 U.S. 91 (1910). See note 45 infra.

43. See cases cited note 20 supra and accompanying text.

44. "The phrase 'interstate commerce' is now commonly understood to describe all trading and movements across state lines, whether of tangible commodities or of intangibles ...." Stern, The Scope of the Phrase Intcrstate Commerce, 41 A.B.A.J. 823 (1955). The agent who enters the state for the purpose of seeking orders for goods to be shipped thereafter into the state has traditionally been called a "drummer" and has been distinguished from the "peddler" who carries his stock of goods with him seeking local sales. See Wagner v. City of Covington, 251 U.S. 95, 103 (1919).

As a practical matter the corporation which only rarely or sporadically enters into transactions admittedly "intrastate" is treated as if it were engaged exclusively in interstate commerce. See International Textbook Co. v. Pigg, 217 U.S. 91, 105 (1910) ; Robbins v. Shelby County Taxing Dist., 120 U.S. 489, $493-94$ (1887) ("But in making such internal regulations a state cannot impose taxes upon persons passing through the state, or coming into it merely for a temporary purpose, especially if connected with interstate or foreign commerce....")

45. The Court said: "Under the authority of the so-called 'drummer' cases . . . Lilly is free to send salesmen into New Jersey to promote [its direct interstate sales to wholesalers] without interference from regulations imposed by the State." 366 U.S. at 278-79. It does not at all appear that this statement indicates a conscious intent to equate tax cases with registration cases in this area, for the Court does not seem to realize that the drummer cases invariably involved tax exactions from the agents soliciting interstate sales. See notes 33 and 34 supra and accompanying text. Nevertheless, it is clear that the drummer situation is protected from state registration, under the Court's assertion here in Lilly and under such a case as International Textbook Co. v. Pigg, 217 U.S. 91 (1910), in which a Kansas registration statute was held invalid as applied to a company sending agents into the state merely to seek customers for correspondence courses mailed out of Pennsylvania. See also Sioux Remedy Co. v. Cope, 235 U.S. 197 (1914).

46. 366 U.S. at 283-84.

47. Cheney Bros. Co. v. Massachusetts, 246 U.S. 147 (1918). See notes 22-23 supra and accompanying text. 
"inducing" found in Lilly plus the added factor of systematic transmission of orders by the promotion men to the wholesalers; under Lilly, registration could be demanded by the state. At the end of the spectrum is the foreign corporation which establishes its own distribution system, factory warehouse, or retail outlet within the state; such activities would clearly subject the corporation to state registration. ${ }^{48}$

The law in the two extremes, cases one and five above, is both firmly established and sound in policy. The asserted justification for requiring the registration is the desire of the state to have a general knowledge of the "corporate presence," ${ }^{49}$ to systematize service of process upon the corporation, ${ }^{, 00}$ and to obtain corporate information so that it may ensure that the business is legitimate and financially responsible. ${ }^{51}$ This justification seems weak in the case of a foreign corporation which does no more than ship goods, and possibly mail circulars, into the state. The state's only interest here is in regulating the safety and character of the goods entering into its commerce. ${ }^{52}$ The general corporate

48. In Union Brokerage Co. v. Jensen, 322 U.S. 202 (1944), for example, a company engaged in "making entry" at customs of goods shipped into the United States from Canada was found to have localized itself for registration purposes in Minnesota where it maintained its actual house of business at the Canadian border, although the business at the brokerage was concerned exclusively with imports and hence "foreign" commerce. The Court stressed the legitimacy of the state's interest in such a localized operation and noted that the small fee which accompanied the license requirement was manifestly only to cover the costs of supervision. Id. at 210-11.

49. "Information expressed in the statement is vital to state authorities to enable them to ascertain corporate presence within the state for subjection to tax laws or regulatory . statutes ... if such taxes and regulations can be applied as a matter of fact and law." Brief of Intervenor-Appellee, State of New Jersey, p. 16.

50. The statute requires, among other things, the appointment of an agent for service of process. See statute cited note 10 supra and accompanying text. The purpose of the requirement has been stated to be the provision for residents of "an easy, certain and expeditious means of serving process on foreign corporations doing business in the State ... " Brief for Appellee Sav-On-Drugs, Inc, p. 15. This designation of an agent for service of process is not, however, essential today for the purposes of securing jurisdiction over foreign corporations in causes of action arising out of business transacted by them in the state. See note 54 infra.

51. "It is a regulation of local activity, designed to insure that the laws will be observed and if not, that there will be a presence of corporate responsibility within the state." Brief of Intervenor-Appellee, State of New Jersey, p. 12. "The ability to examine the charter insures the impartation of legitimacy to any corporation whose business affairs will be conducted within the State of New Jersey. Absent the necessity of such corporate revelation, a business association might conduct its affairs, through subterfuge, in the guise of a corporation, and thus enjoy the legitimate benefits accruing to a foreign corporation without in fact being one." Id. at p. 15. (Cf. "Obviously if a 'business association' is not really a corporation the qualification statute does not apply to it at all." Reply Brief for Appellant, Eli Lilly and Company, p. 14, footnote.) "The corporate charter would also reveal if a corporation properly organized had as a stated purpose for its existence an activity proscribed by the laws of this state." Brief of Intervenor-Appellee, State of New Jersey, p. 15.

52. Drug products in particular are subject to regulation. Lilly drugs sent into New Jersey must presumably meet the standards of both the federal food and drug legislation 
registration statute does not further such regulation appreciably because specific knowledge of infringements is still required for enforcement. ${ }^{53}$ Also, such a corporation presently can be made subject to service of process at least as to actions arising out of business transacted in the state even without formal designation of a resident agent $;^{5-4}$ and, since the state has little legitimate interest in securing jurisdiction over actions foreign to its borders, ${ }^{55}$ it does not seem fair to permit the state to use the registration statute to secure jurisdiction for this purpose. ${ }^{56}$ The state's interest in corporate financial responsibility

and the New Jersey requirements set out in N.J. REV. STAT. $\$$ 24:1-1 through 24:6A-1 (1937).

53. The state obviously has no power to police the goods at their source, since their manufacture takes place outside the state. Furthermore, if police power regulations were set up concerning the goods themselves once they had entered the state, specific inspection of goods at the place of receipt or sale would still be necessary to discover infringements and violations: knowledge of "corporate presence" imparts nothing whatever about the commodities shipped in.

54. This is a question not of the commerce clause but of due process. The leading case is International Shoe Co. v. Washington, 326 U.S. 310 (1945), which considered whether the state could secure jurisdiction over a foreign corporation by service upon a salesman and by registered mail where the corporation maintained an active sales force in the state to exhibit samples but forward orders out of the state for acceptance. The Court, through Mr. Chief Justice Stone, held that due process had been met. The Court set up as a test whether "these operations establish sufficient contacts or ties with the state of the forum to make it reasonable and just, according to our traditional conception of fair play and substantial justice, to permit the state to enforce the obligations which appellant has incurred there." Id. at 320. This is generally known as the "minimum contacts rule." Since then the doctrine has been developed to require only the merest business contact to validate jurisdiction over a foreign corporation as to a cause of action arising out of such business. See McGee v. International Life Ins. Co., 355 U.S. 220 (1957) ; Travelers Health Ass'n v. Virginia, 339 U.S. 643 (1950) ; cf. Hanson v. Denckla, 357 U.S. 235 (1958). See discussion of recent developments expanding state power to secure jurisdiction over foreign corporations, in MoORe, Federal Practice, Rules and OfFICIAL Foriss $470-75$ (1961).

55. The absence of pressing state interest in causes of action unconnected with the forum state is reflected in the situation where a state opens its courts to its own citizens for suits upon causes of actions arising outside of the state but chooses to refuse to provide a forum for similar actions brought by non-residents of the state. Such treatment of the non-resident is permissible under the "privilege and immunities clause," U.S. CoNST. art. IV, $\S 2$, because the distinction is based upon "rational considerations." See Douglas v. New York, N.H. \& H.R.R., 279 U.S. 377 (1929).

56. Under the doctrine of "unconstitutional conditions" the state's acknowledged power to grant or withhold the right to do "domestic" business (see Paul v. Virginia, 75 U.S. (8 Wall.) 168 (1868) and Railway Express Agency v. Virginia, 282 U.S. 440 (1931)) cannot be used as a whip to secure a foreign corporation's surrender of what would otherwise be a constitutional right. See generally Merrill, Unconstitutional Conditions, 77 U. PA. L. REv. 879 (1929) ; Comment, Unconstitutional Conditions and Constitutional Rights, 35 Colum. L. Rev. 321 (1935) ; Henderson, The Position of Foreign Corporations in American Constitutional Law 132-47 (1918). If state registration of a foreign corporation doing business only by mail were permitted as a legitimate exercise of the police power designed to give the state knowledge of "corporate presence," the coupling of the fequirement of designation of an agent for service of process might still remain unconstifutional on grounds of due process under the "minimum contacts rule" of International 
as expressed in the requirement of filing corporate papers seems to be an equally weak justification. It may be assumed that the state of incorporation is already requiring the company to file information and to comply with supervisory legislation, ${ }^{57}$ and multiple supervision would seem superfluous here. The federal interest on the other hand appears more significant. The burden involved would lie chiefly in the time and expense inherent in the necessary paperwork. ${ }^{58}$ This burden could be substantial for a corporation doing business in many states and as a result subject to multiple registration, ${ }^{60}$ particularly in the case of a company doing only a small amount of business in each state. ${ }^{60}$ The only alternative to such compliance would seem to be an abandon-

Shoe Co. v. Washington, 326 U.S. 310 (1945), as to actions foreign to the state. See note 54 supra.

An important but unadjudicated question is whether the state may demand, as a condition precedent to doing business, express consent to service on a statutory agent as to foreign causes of action unconnected with business transacted within the state. It may well be that the question will be negatively answered when it is presented for adjudication, since the state may not constitutionally assume such jurisdiction in the absence of consent, and therefore a provision compelling consent to an assumption of jurisdiction otherwise unconstitutional may be regarded as an unconstitutional condition.

Note, The Adoption of the Liberal Theory of Foreign Corporations, 79 U. PA. L. Rev. 1119,1130 (1930). The question as to causes of action arising within the state ought not to arise, however, as the law stands today, because the "minimum contacts rule" will clearly be satisfied long before the business is deemed "local" enough to merit state registration.

In Sioux Remedy Co. v. Cope, 235 U.S. 197 (1914), the Court struck down a state corporate registration statute as applied to a corporation determined to be doing a purely interstate business. The Court commented that the provision "respecting the appointment of a resident agent upon whom process may be served, is particularly burdensome, because ... it requires the corporation to subject itself to the jurisdiction of the courts of the State in general as a prerequisite to suing in any of them ...." Id. at 205.

57. The typical process of incorporation is notorious for its demands as to the filing of papers and compliance with state requirements. See, e.g., IND. ANn. STAT. $\$ \S 25-101$ to -265 and $25-401$ to -427 (1960). Papers filed for the purposes of incorporation are generally public records and available to all upon request.

58. The requirements of the registration procedure are set forth in the text supra beginning at note 9 . In addition, the registered company must keep the information filed upto-date by means of an annual report setting forth each time substantially the same information as contained in the initial registration plus lists of the directors of the company with addresses and a notice of the date of the annual stockholders' meeting. N.J. Rev. STAT. \& 14:6-2 (1937).

59. It seems that every state has statutes providing for the registration of foreign corporations seeking to come in to transact business. See, e.g., Ind. ANn. STur. $\S \S 25-301$, 25-305, 25-306, 25-314 (1960) ; N.Y. Bus. CoRP. LAW \$§ 1301, 1303, 1304, 1312; Onio Rev. Code Ann. $\S \S 1703.03,1703.27,1703.29,1703.99$ (1953) ; CAL. Corp. Code $\$ \S 6400,6401$, $6403,6500,6801,6802$.

60. Eli Lilly and Company apparently considered the registration sufficiently burdensome to warrant an appeal in the case all the way to the Supreme Court; to save the Fair Trade suit from dismissal Lilly could have registered at any time, even while the action was pending. See Peter Doelger Brewing Corp. v. Spindel, 14 N.J. Misc. 523, 186 Atl. 429 (1936). 
ment of the interstate sales themselves, ${ }^{61}$ which would clearly be an undue interference.

At the other extreme, in case five above, the state should be permitted to require registration of a business which localizes itself physically and economically to the extent of operating a local retail sales branch or a factory warehouse. A line must be drawn at some point, even though an element of arbitrariness will be present in any boundary set; given this problem, a line excluding case five above from the protection of the commerce clause seems a reasonable one. It is satisfactory conceptually because, in a sense, the manufacturer is conducting a separate "intrastate" business-that of selling at retail his goods which, although originally shipped in interstate commerce, have now "come to rest" within the state. ${ }^{62}$ Moreover, the presence of a substantially "localized" business operation may be viewed as giving rise to peculiarly state interests in the company's conduct, ${ }^{63}$ both as to financial responsibility and as to police power regulation of the actual conduct of the corporation. ${ }^{64}$ In terms of fairness, such subjection to registration is a mere equalization of the business conditions imposed upon all local merchants. Finally, while the actual burden of registration on the foreign corporation is of course the same as in case one above, the manufacturer conducting such a local sales business has available at least some alternative, since these sales activities can be abandoned without total impairment of his ability to solicit and promote interstate sales.

61. Of course, the various burdens inherent in the registration scheme come into play only when the state and the courts choose to enforce them. If registration of a foreign corporation doing business in the state only by mail were permitted and if the state chose to undertake full enforcement of the registration requirement, the choice for the corporation would clearly be between submission to the burdens of the statute and abandonment of the interstate sales themselves in the face of state fines and possibly injunctions for failure to register. If the state chose not to implement the registration requirement as to such a foreign corporation, interstate sales might still be curtailed by reason of the unenforceability of the corporation's contracts in the state. See note 11 supra and accompanying text.

62. The "coming to rest" concept is derived from a long series of cases. See, e.g., Brown v. Houston, 114 U.S. 622, 634 (1885) ("property which had reached its destination, and had become part of the general mass of property ...."); Brown v. Maryland, 25 U.S. (12 Wheat.) 419,441 (1827) ("it has become incorporated and mixed up with the mass of property in the country ... "); Woodruff v. Parham, 75 U.S. (8 Wall.) 123 (1868); Youngstown Sheet \& Tube Co. v. Bowers, 358 U.S. 534 (1959).

63. See Union Brokerage Co. v. Jensen, 322 U.S. 202 (1944). "The business of Union ... is localized in Minnesota, and Minnesota, in the requirement before us, merely seeks to regularize its conduct." Id. at 211. "The Commerce Clause does not deprive Minnesota of the power to protect the special interest that has been brought into play by Union's localized pursuit of its share in the comprehensive process of foreign commerce." Id. at 211-12. See note 48 supra.

64. To be logically consistent a validation of registration on a finding of "localized" business should extend only to that part of the foreign corporation carrying on that business. As a practical matter, of course, a corporation is a unit and can only be registered as such, although "partial registration" would in effect be possible where the "local business" is conducted by a corporate unit legally separate from the parent manufacturer. 
The boundary of state power must therefore be set at some point between the extreme cases, one and five above. Arguably it could be drawn between case one, the simple situation of the corporation doing business from afar, and case two, the drummer scheme. An apparent ground for distinguishing these two situations is the personal presence, in the latter, of representatives of the absent manufacturer. This additional factor, however, does not materially vary the character of any state interest in goods which enter its commerce; nor should it increase the state's interest in the over-all capital structure of the corporation. ${ }^{65}$ Moreover, the registration statute is inappropriate to meeting any risks peculiar to the fact of personal selling activities, ${ }^{66}$ for mere general knowledge of "corporate presence" will not significantly aid the state in preventing unlawful acts by the personnel. ${ }^{67}$ While registration may serve to systematize service of process through appointment of agents, process may clearly be served without such registration upon a corporation sending drummers into the state. ${ }^{68}$ It is true that the drummer activities could perhaps be viewed conceptually as those of a local independent "advertising agency" and thus "intrastate." Realistically, however, such a label is inaccurate, for the drummers are in no way operating as a separate business, but are mere employees, salaried for the sole purpose of promoting the interstate sales of their employer. ${ }^{69}$ This relationship to interstate commerce is the basis of the drummer decisions, which expressly assert that the drummers may not be subjected

65. It might be argued that the state's interest in the commerce is increased because the persuasive powers of the detailmen will increase the quantities of goods sold, but this hardly changes the character of any such interest. In any case, interest in the safety and character of the goods themselves is a weak justification for the filing of information concerning the over-all capital structure of the corporation.

66. Such risks might be met by a statute requiring the posting of a bond to guarantee the conduct of the drummer. In California v. Thompson, 313 U.S. 109 (1941), the Court upheld a state statute requiring a license and bond as applied to a transportation agent dealing exclusively in interstate transportation. The Court termed the statute "a measure to safeguard the members of the public desiring to secure transportation by motor vehicle, who are peculiarly unable to protect themselves from fraud and overreaching of those engaged in a business notoriously subject to those abuses." Id. at 112-13. That case in effect overruled DiSanto v. Pennsylvania, 273 U.S. 34 (1927). Compare Real Silk Hosiery Mills v. Portland, 268 U.S. 325 (1925), striking down a city ordinance requiring that every person going from place to place taking orders for future delivery should secure a license and file a bond. The Court relied upon the drummer cases and added, "Nor can we accept the theory that an expressed purpose to prevent possible frauds is enough to justify legislation which really interferes with the free flow of legitimate interstate commerce." Id. at 336 .

67. This is the same problem as that concerning the supervision of the goods themselves. See note 53 supra and accompanying text. In either case the advance knowledge of "corporate presence" will not be a substitute for knowledge of actual violations and infringements.

68. See notes 54 and 56 supra. The crux of the matter is that this is a problem of due process and not of the commerce clause at all.

69. See 57 N.J. Super. at 298-99, 154 A.2d at 654. 
to state license tax requirements because their activities are essential to the sale of goods in interstate commerce. ${ }^{70}$

The Court in Lilly, while acknowledging the immunity of the drummer situation from state registration, ${ }^{71}$ chose to draw the boundary of state power between cases two and three above, so as to exclude the Lilly situation from the protection of the commerce clause. This distinction between the two situations, however, appears indefensible in terms of the actual interests involved. The essential factor in each of the cases is that there are agents of the manufacturer personally present in the state seeking to promote the sales of the products through direct persuasion and inducement. The substitution of the retailers and physicians for the direct interstate customers of the manufacturer as the objects of this persuasion would not seem to make the company any more "present" for purposes of the justifications underlying the compulsory registration. ${ }^{72} \mathrm{Mr}$. Justice Harlan, however, in his concurring opinion asserted that while the promotion activities in the drummer cases were essential to the existence of the interstate sales, the promotion activities of the Lilly detailmen were not so essential. Lilly, he argued, can abandon its detailmen system to escape registration and still remain free to solicit direct sales of its drugs to wholesalers and even to retailers if it is willing to sell directly and eliminate the wholesaler altogether; the company must register only because it prefers its indirect promotion scheme. ${ }^{73}$ It seems clear, nevertheless, that the "detailman" is as essential to the interstate sales system in today's drug market as the drummer was in the nineteenth century sales context out of which the drummer doctrine arose. ${ }^{74}$ The wholesaler by nature is as much a buying agent for the retailer as he is a selling agent for the manufacturer; his essential buying service is the bringing together of the multitude of products needed by the retailer, a service resulting in the handling of many competing products. ${ }^{75}$ It

70. E.g., "How is a manufacturer, or a merchant, of one state, to sell his goods in another state, without, in some way, obtaining orders therefor?" Robbins v. Shelby County Taxing Dist., 120 U.S. 489, 494 (1887). "It may be suggested that the merchant or manufacturer has the post-office at his command, and may solicit orders through the mails. We do not suppose, however, that any one would seriously contend that this is the only way in which his business can be transacted without being amenable to exactions on the part of the state. Besides, why could not the State to which his letters might be sent, tax him for soliciting orders in this way, as well as in any other way?" Id. at 495. "The negotiation of sales of goods which are in another state, for the purpose of introducing them into the state in which the negotiation is made, is interstate commerce." Id. at 497.

71. See note 45 supra.

72. See notes 49-51 supra and accompanying text.

73. 366 U.S. at 286. Mr. Justice Harlan asserted: "Petitioner remains free, and is constitutionally entitled to remain free, to solicit purchases directly by New Jersey retailers and consumers or, alternatively, to rely on its wholesalers to develop the New Jersey market." Ibid.

74. "The drummer is a figure representative of a by-gone day. But his modern prototype persists under more euphonious appellations. So endure the basic reasons which brought about his protection ...." Nippert v. Richmond, 327 U.S. 416, 435 (1946).

75. See Beckman, Wholesaling 6-14 (1939); Bureau of Foreign and Domestic Comirierce, U.S. Dep't of Commaree, Wholesale Druggists' Operations 1-4 (1934). 
is thus clear that a manufacturer cannot rely upon the wholesaler for special promotion of his product alone. Moreover, the wholesaler is a distributing device only, with neither the resources nor the inclination to master the rapidly changing technical knowledge essential in the promotion of drugs. Thus, detailmen, knowledgeable in their field and armed with the latest information and developments of their manufacturer, must be provided to contact directly the men who most influence the drug market, the physicians who prescribe the "ethical" drugs for their patients and the druggists who are called upon to suggest the "proprietary" drugs products for their customers and who select the brands to be used in filling prescriptions where the physician has made no specification. ${ }^{76}$ The detailman, together with direct mailings to the physician and to a lesser extent the advertisement in the medical journal, constitutes the basic selling mechanism of the modern drug industry. ${ }^{77}$

Lastly, in view of the interests examined above as to promotion situations two and three, there is clearly no reason to distinguish between those cases and the situation in case four, which involves the "inducing" of sales plus the added factor of systematic transmission of orders by the promotion men to the wholesalers. ${ }^{78}$ This added factor is a mechanical and insignificant task from

76. See generally Hearings on Drug Industry Antitrust Act Bcfore the Subcommittce on Antitrust and Monopoly of the Senate Committee on the Judiciary, 87th Cong., 1st Sess. (1961) [hereinafter cited as Hearings]. The practitioner often has to prescribe the latest drugs on the basis of materials supplied in this fashion "because the information from the detail man is brought to him before it gets into any other source." Statement of Dr. Walter Modell, Cornell University Medical College, Hearings at 319. "Good, fast detailing is the best means of communicating with us. It's the personal contact that counts. We don't have time to go through the professional literature, and the detail man can provide us everything we need." Comment of Dr. G.P.S., reported in "Fond du Lac [Wisconsin] Study," prepared for the American Medical Association (1956), printed in Hearings, Appendix at 727. "The other media are too uncertain and leave it up to the doctor to sort it out." Comment of Dr. P.T.B., "Fond du Lac Study," Hearings, Appendix at 727. See also other sections of the Study, Hearings, Appendix at 743-806.

Much of the testimony at the hearings was critical of the sums of money being spent on advertising in the drug industry today, including amounts required to maintain the detailmen system. But the hearings amply corroborate the conclusion that the detailman occupies the central position in the sales of "ethical" drugs, through his effect on the prescribing physician. This conclusion is also supported by Silberman, Drugs: The Pace is Getting Furious, Fortune, May 1960, p. 138, which is similarly critical of the expense involved but verifies the role of the detailman. The article particularly cites the necessity of getting to the physician with new developments as soon as possible as being a major factor in the importance of the detailman. Id. at 275.

77. Statement of Dr. Charles D. May, N.Y.U. School of Medicine, Hearings at 181. "Detail men and articles in medical journals are selected by the most physicians in the Fond du Lac area as their most important sources of information about new drugs." "Fond du Lac Study," Hearings, Appendix at 725. "Five companies are each named by more than one Fond du Lac physician as usually doing 'the best job of detailing': Eli Lilly, named by 9 doctors; Parke Davis, by 8 ; Abbott, by 5 ; Hoffman La Roche, by 3; and Upjohn, by 3." Hearings, Appendix at 727.

78. The Lilly detailmen actually did transmit such orders "occasionally," but the Court's opinion is founded on the concept that the essence of their activities was a general "inducing" of local sales. See note 80 infra. 
which no conceivable state interest can be said to arise. Thus the majority in Lilly was correct in viewing the promotion schemes in Lilly and Cheney ${ }^{7 \theta}$ as essentially similar. ${ }^{80}$ The Court's basic error was in assuming that the label selected in Cheney, for purposes of upholding a tax, should apply in Lilly, for purposes of upholding registration, merely because the two promotion systems were alike.

79. Cheney Bros. Co. v. Massachusetts, 246 U.S. 147 (1918). See notes 22-23 supra and accompanying text.

80. "It is true that the record in the Cheney case shows a more regular solicitation of orders than does the record here. But that difference is not enough to distinguish the cases." 366 U.S. at 282. 